\title{
SECONDARY SYPHILIS WITH OCULAR INVOLVEMENT IN A HIV-INFECTED PATIENT - CASE REPORT
}

\author{
KIŁA DRUGIEGO OKRESU Z ZAJĘCIEM NARZĄDU WZROKU \\ U PACJENTA ZAKAŻONEGO HIV - OPIS PRZYPADKU
}
Department of Dermatology and Venereology, Medical University of Bialystok, Poland Klinika Dermatologii i Wenerologii, Uniwersytet Medyczny w Białymstoku

\begin{abstract}
We describe the case of a HIV-infected patient, in whom a secondary syphilis with skin lesions and ocular involvement developed.

On admission papular skin rash and partial visual loss with left eye were observed. Serological tests for syphilis were positive in very high titers. Ophthalmological examination revealed ocular abnormalities indicating ocular syphilis. Cerebrospinal fluid (CSF) tests showed elevated concentration of immunoglobulin G (IgG) with normal white blood count and albumin concentration, serological treponemal tests for syphilis were positive.

Intravenous therapy with Penicillinum Crystallisatum (Benzylpenicillinum kalicum) was administered, according to the neurosyphilis treatment schedule, achieving resolution of the skin lesions and partial vision improvement, a month after the end of the treatment a complete recovery of the vision was noted. Serological tests' for syphilis titers decreased fourfold.

Described case confirms reasonability of examination for syphilis in patients with sudden vision disturbances, especially those HIV-infected. It also indicates that early appropriate treatment of the ocular syphilis prevents permanent loss of vision.
\end{abstract}

Key words: ocular syphilis, HIV, neurosyphilis, syphilis diagnostics, syphilis treatment

\section{STRESZCZENIE}

Prezentujemy przypadek chorego zakażonego HIV, u którego wystąpiła kiła wczesna nawrotowa z objawami skórnymi i zajęciem narządu wzroku.

Przy przyjęciu stwierdzono osutkę grudkową i częściową utratę widzenia lewym okiem. Kiłowe odczyny serologiczne były dodatnie o bardzo wysokich mianach. Badanie okulistyczne wykazało odchylenia mogące odpowiadać kile narządu wzroku. W płynie mózgowo-rdzeniowym (PMR) stwierdzono podwyższone stężenie immunoglobuliny $\mathrm{G}$ ( $\mathrm{IgG}$ ) przy prawidłowej cytozie i stężeniu albumin oraz dodatnie kiłowe odczyny krętkowe. Wdrożono leczenie penicyliną krystaliczną dożylnie, według schematu leczenia kiły ośrodkowego układu nerwowego (OUN). Uzyskano ustąpienie zmian skórnych i częściową poprawę widzenia, po miesiącu od zakończenia leczenia całkowity powrót widzenia. Miana kiłowych odczynów serologicznych uległy czterokrotnemu obniżeniu.

Opisywany przypadek potwierdza zasadność diagnostyki w kierunku kiły u osób z nagłymi zaburzeniami widzenia, zwłaszcza u pacjentów zakażonych HIV. Wskazuje również, że odpowiednio szybkie podjęcie adekwatnego leczenia pomaga zapobiec trwałej utracie wzroku.

Słowa kluczowe: kita narządu wzroku, HIV, kiła OUN, diagnostyka kity, leczenie kity 


\section{INTRODUCTION}

Syphilis is a disease caused by the spirochete Treponema pallidum, most often transmitted sexually or vertically. According to the literature, the number of syphilis cases has been increasing since 2000, especially in the group of homosexual men (men who have sex with men, MSM) (1-4).

In the course of untreated acquired syphilis, we can distinguish early syphilis, lasting up to one year after infection - according to the Centers for Disease Control and Prevention (CDC) or two years according to the World Health Organization (WHO), late syphilis and asymptomatic syphilis. Early syphilis includes first-stage syphilis lasting up to 3 months after infection, and recurrent (second-stage) syphilis. First-stage syphilis is manifested by the occurrence of one, less often numerous, painless ulcers at the area of a pathogen penetration. In the second stage of the disease, the infection is generalized and various organs are involved. Mucocutaneous lesions are macular or papular rash and / or alopecia, vitiligo, condylomata lata or angina. Approximately $28 \%$ of untreated patients develop late (third stage) syphilis after 2-5 years, with possible symptoms in the skin, internal organs, also the nervous and cardiovascular systems (5). Syphilis of the central nervous system and eye are now less common forms of the disease, however, they can develop at any stage of this spirochetal infection.

Syphilis can coexist with other sexually transmitted infections, including HIV. According to the latest report of the European Center for Disease Prevention and Control (ECDC), in 2018 among syphilis infected patients tested for HIV, $24 \%$ were HIV positive, in the MSM population it was $35 \%$ (3).

\section{OBJECTIVE OF THE STUDY}

The aim of the study is to present a case of an HIVinfected patient who developed second-stage syphilis with an ocular involvement.

\section{A CASE REPORT}

A thirty-three-year-old patient, bachelor, sales worker, treated since 2018 due to a retroviral disease with a low number of CD4+ lymphocytes, was admitted to the Department of Dermatology in October 2020 due to generalized papular rash lasting for 5 weeks and positive syphilitic serologic reactions. The test for syphilis by the electrochemiluminescence method ECLIA (Cobas ${ }^{\circledR}$ Roche, Mannheim) was negative two years ago.

On admission to the hospital, the patient reported loss of central vision with the left eye lasting for

\section{WSTĘP}

Kiła jest chorobą wywoływaną przez krętek blady Treponema pallidum, przenoszoną najczęściej drogą kontaktów seksualnych lub wertykalną. Według danych piśmiennictwa, od 2000 r. wzrasta liczba przypadków kiły, szczególnie w grupie homoseksualnych mężczyzn (men who have sex with men, MSM) (1-4).

W przebiegu nieleczonej kiły nabytej wyróżnia się kiłę wczesną, trwającą do roku od zakażenia - według Centers for Disease Control and Prevention (CDC), lub dwóch lat - według World Health Organization (WHO), kiłę późną i kiłę bezobjawową. Kiła wczesna obejmuje kiłę pierwszego okresu o czasie trwania do 3 miesięcy od zakażenia i kiłę nawrotową (drugiego okresu). Kiła pierwszego okresu manifestuje się wystąpieniem najczęściej jednego, rzadziej licznych niebolesnych owrzodzeń w miejscu wniknięcia patogenu. W drugim okresie choroby zakażenie ma charakter uogólniony i dochodzi do zajęcia różnych narządów. Zmiany skórno-śluzówkowe charakteryzują się osutką plamistą lub grudkową i/lub łysieniem, bielactwem, kłykcinami płaskimi czy anginą. U ok. $28 \%$ chorych nieleczonych rozwija się po 2-5 latach kiła późna (trzeciego okresu) z możliwością wystąpienia objawów ze strony skóry, narządów wewnętrznych oraz układu nerwowego i sercowo-naczyniowego (5). Kiła ośrodkowego układu nerwowego i narządu wzroku są obecnie rzadziej spotykanymi postaciami, jednakże mogą rozwinąć się na każdym etapie zakażenia krętkiem bladym.

Kiła może współistnieć z innymi chorobami przenoszonymi drogą płciową, m.in. zakażeniem HIV. Według ostatniego raportu European Centre for Disease Prevention and Control (ECDC), w 2018 r. wśród pacjentów z kiłą badanych w kierunku HIV odsetek zakażonych tym wirusem wynosił $24 \%$, a w populacji MSM sięgał $35 \%$ (3).

\section{CEL PRACY}

Celem pracy jest przedstawienie przypadku chorego zakażonego HIV, u którego wystąpiła kiła drugiego okresu z zajęciem narządu wzroku.

\section{OPIS PRZYPADKU}

Trzydziestotrzyletni pacjent, kawaler, pracownik handlowy, leczony od 2018 r. z powodu choroby retrowirusowej z niską liczbą limfocytów CD4+, został przyjęty do Kliniki Dermatologii w październiku 2020 r. z powodu uogólnionej osutki grudkowej występującej od 5 tygodni i dodatnich kiłowych odczynów serologicznych. Badanie w kierunku kiły metodą elektrochemiluminescencji ECLIA (Cobas ${ }^{\circledR}$ Roche, Mannheim) przed dwoma laty było ujemne. 
2 weeks. The interview revealed that the patient had casual sexual contacts with men and women. According to him, the last contact was a year earlier.

On admission, a dermatological examination revealed in the skin of the trunk, limbs and face an asymmetrical rash in the form of erythematous papules, partially hypertrophic, with the presence of scabs and peripheral collar-shaped exfoliation (Fig. 1-3). Within the soles and palms - flattened papules with marginal scaling were found. There were extensive, oozing condylomata lata with maceration around the anus. In addition, there were palpable axillar and ulnar lymph nodes of a pea size.
Przy przyjęciu do Kliniki chory zgłaszał występującą od 2 tygodni utratę widzenia centralnego okiem lewym. Z wywiadu ustalono, że pacjent odbywał przygodne kontakty seksualne z mężczyznami i kobietami. Według jego relacji, ostatni kontakt miał miejsce rok wcześniej.

Przy przyjęciu badaniem dermatologicznym stwierdzono w zakresie skóry tułowia, kończyn i twarzy niesymetryczną osutkę o charakterze grudek rumieniowych, miejscami przerosłych, $\mathrm{z}$ obecnością strupów i obwodowego kołnierzykowatego złuszczania (Ryc. 1-3). W obrębie podeszew i dłoni - spłaszczone grudki z obwodowym złuszczaniem. Wokół odbytu stwierdzono rozległe, sączące kłykciny płaskie z cechami maceracji. Ponadto były wyczuwalne palpacyjnie węzły chłonne pachowe i łokciowe wielkości ziarna grochu.

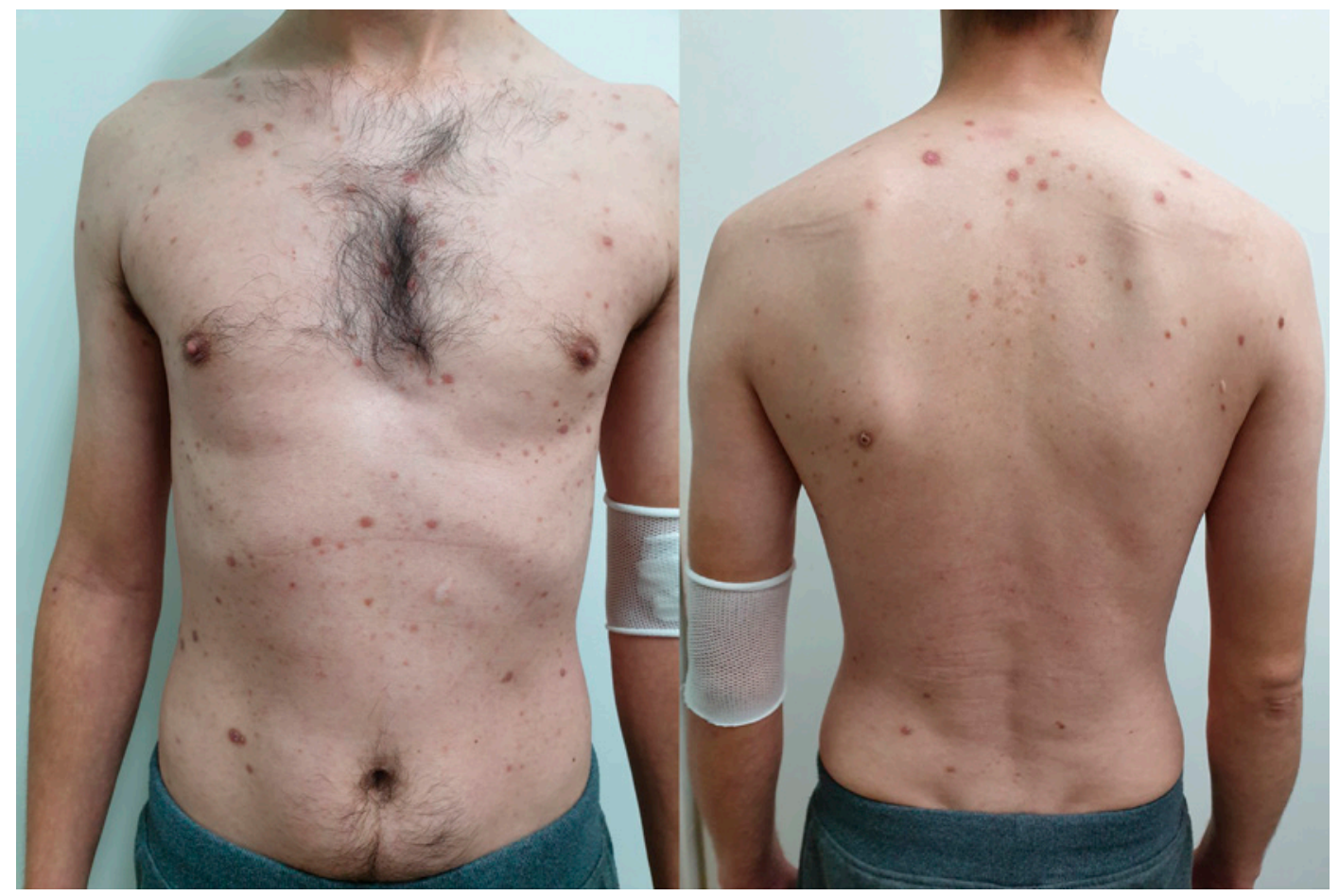

Fig. 1. Disseminated asymmetrically distributed papulosquamous eruption on the trunk

Ryc. 1. Rozsiana niesymetryczna osutka grudkowo-złuszczająca w obrębie tułowia

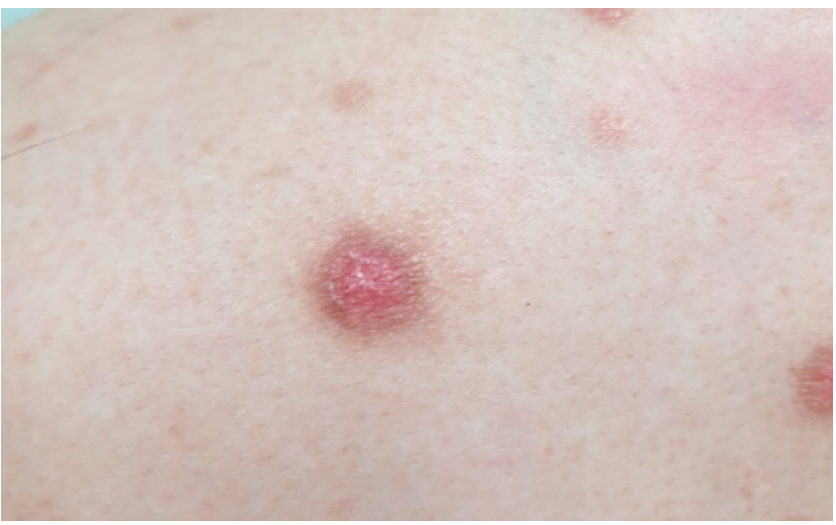

Fig. 2. Hypertrophic papule with peripheral scaling

Ryc. 2. Przerosła grudka z kołnierzykowatym złuszczaniem

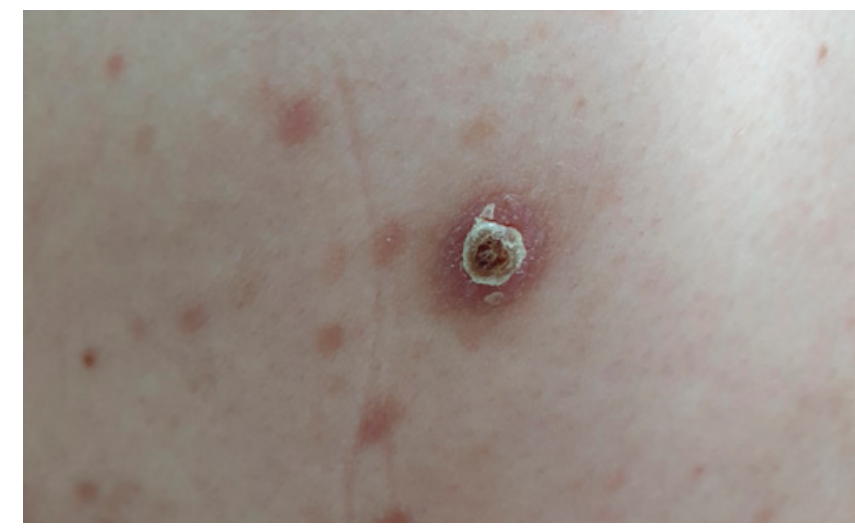

Fig.3. Hypertrophic papule covered with crust Ryc. 3. Przerosła grudka pokryta strupem 
Laboratory blood tests showed extremely high rates of tests for syphilis: Venereal Disease Research Laboratory test (VDRL) 1/256 (Biomed, Kraków), Treponema Pallidum Hemaglutination Test (TPHA) 1/40960 (Bio-Rad, Marnaes-la Coquette, France), Fluorescent Treponemal Antibody (FTA) 1/72000 (Diagnostic and Research Center for Sexually Transmitted Diseases, Białystok), Fluorescent Treponemal Antibody Absorption Test (FTA-ABS) positive (Diagnostic and Research Center for Sexually Transmitted Diseases, Białystok), Nelson spirochete immobilization test positive - 100\% (Diagnostic and Research Center for Sexually Transmitted Diseases, Białystok). Tests for other sexually transmitted infections were negative. Other laboratory examinations showed an elevated CRP concentration $(66.7 \mathrm{mg} / 1[\mathrm{~N}<5])$, an increased activity of liver enzymes (ALT $70 \mathrm{U} / 1$ [ $\mathrm{N}<41]$, AST $55 \mathrm{U} / 1[\mathrm{~N}<38]$, GGTP 413 U/1 [N 5-61]), decreased number of CD4+ T cells $72 / \mu 1$ (N 404-1612). The ultrasound examination of the abdominal cavity revealed a slightly enlarged liver, with insensibly increased echogenicity, granular echostructure, with a single lymph node of a size $21 \times 8 \mathrm{~mm}$ in the hilum. Echocardiography didn't show any significant abnormalities.

The ophthalmological examination demonstrated a reduced visual acuity (0.4) and an opalescent lens in the left eye. The fundus examination revealed a discreetly altered reflex of the macula, with a line corresponding to a history of central serous retinopathy. In optical coherence tomography (OCT) of the left eye's macula, folding of the retinal pigment epithelium was found. Neurological examination showed no obvious symptoms of focal CNS damage. In the otorhinolaryngological examination, no significant abnormalities were found.

Magnetic resonance imaging of the brain and brainstem with contrast was performed. Cortical atrophy of the brain, hemispheres and the cerebellar vermis, enlargement of the periocerebral spaces up to 6-7 mm, and thickening of the mucous membrane of the maxillary, frontal, sphenoid and ethmoid sinuses were found. The cerebrospinal fluid (CSF) tests revealed cytosis of 5 leukocytes $/ \mathrm{mm}^{3}$, including mononuclear cells $3 / \mathrm{mm}^{3}$, albumin $16.26 \mathrm{mg} / \mathrm{dl}$ [N 10-30] and increased concentration of immunoglobulin $\mathrm{G}(\mathrm{IgG})$ $88.65 \mathrm{mg} / 1$ [N 10-30]. In the CSF spirochetal tests for syphilis were positive FTA 1/75 and TPHA 1/64, VDRL was negative.

On the basis of the overall clinical examination and the results of additional tests, the second stage syphilis, involving the left eye and the liver was diagnosed. Treatment with crystalline penicillin intravenously with 4 million units every 4 hours for 14 days was performed. On the first day of the drug's administration,
W badaniach laboratoryjnych krwi z istotnych odchyleń od normy stwierdzono wybitnie dodatnie odczyny kiłowe: Venereal Disease Research Laboratory test (VDRL) 1/256 (Biomed, Kraków), Treponema pallidum Hemaglutination Test (TPHA) 1/40960 (Bio-Rad, Marnaes-la Coquette, Francja), Fluorescent Treponemal Antibody (FTA) 1/72000 (Ośrodek Diagnostyczno-Badawczy Chorób Przenoszonych Drogą Płciową, Białystok), Fluorescent Treponemal Antibody Absorption Test (FTA-ABS) dodatni (Ośrodek Diagnostyczno-Badawczy Chorób Przenoszonych Drogą Płciową, Białystok), odczyn immobilizacji krętków Nelsona dodatni - 100\% (Ośrodek Diagnostyczno-Badawczy Chorób Przenoszonych Drogą Płciową, Białystok). Wyniki badań w kierunku innych zakażeń przenoszonych drogą płciową były ujemne. Pozostałe badania laboratoryjne wykazały: podwyższone stężenie CRP $(66,7 \mathrm{mg} / 1$ $[\mathrm{N}<5]$ ), wzrost aktywności enzymów wątrobowych (ALT $70 \mathrm{U} / 1$ [ $\mathrm{N}<41]$, AST $55 \mathrm{U} / 1$ [ $<$ 38], GGTP 413 U/1 [N 5-61]), obniżoną liczbę limfocytów T CD4+

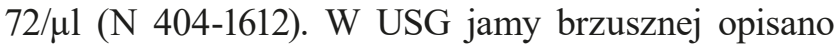
wątrobę granicznej wielkości, o nieco wzmożonej echogeniczności, ziarnistej echostrukturze, z pojedynczym węzłem chłonnym o wymiarach 21 x $8 \mathrm{~mm}$ we wnęce. W echokardiografii nie stwierdzono istotnych odchyleń od normy.

$\mathrm{W}$ badaniu okulistycznym $\mathrm{z}$ odchyleń stwierdzono w oku lewym obniżoną ostrość widzenia $(0,4)$, soczewkę opalizującą. Badanie dna oka wykazało plamkę z refleksem dyskretnie zmienionym, $\mathrm{z}$ linią odpowiadającą przebytej centralnej surowiczej retinopatii. W optycznej tomografii koherencyjnej (OCT) plamki oka lewego stwierdzono pofałdowanie nabłonka barwnikowego siatkówki. Badaniem neurologicznym nie stwierdzono ewidentnych objawów ogniskowego uszkodzenia OUN. Badaniem otorynolaryngologicznym nie stwierdzono istotnych odchyleń od normy.

Wykonano rezonans magnetyczny mózgu i pnia mózgu z kontrastem: z odchyleń opisano zanik korowy mózgu, półkul i robaka móżdżku, poszerzenie przestrzeni przymózgowych w okolicach czołowociemieniowych do 6-7 $\mathrm{mm}$ oraz przyścienne zagęszczenia w zatokach szczękowych, czołowych, klinowych i sitowiu. W badaniu płynu mózgowo-rdzeniowego (PMR) stwierdzono cytozę 5 leukocytów $/ \mathrm{mm}^{3}$, w tym jednojądrzaste $3 / \mathrm{mm}^{3}$, albuminy $16,26 \mathrm{mg} / \mathrm{dl}$ [N 10-30] i podwyższone stężenie immunoglobuliny $\mathrm{G}$ (IgG) $88,65 \mathrm{mg} / \mathrm{l}$ [N 10-30], oraz dodatnie krętkowe odczyny w kierunku kiły FTA 1/75 i TPHA 1/64, odczyn VDRL ujemny.

Na podstawie całości obrazu klinicznego i wyników badań dodatkowych rozpoznano kiłę drugiego okresu z zajęciem narządu wzroku i wątroby. Wdrożono leczenie penicyliną krystaliczną dożylnie $4 \mathrm{mln} \mathrm{j}$. co 4 godziny przez 14 dni. W pierwszym dniu podawania leku wystąpiła reakcja Jarisha-Łukasiewicza-Herxheimera 
a Jarish-Łukasiewicz-Herxheimer reaction in the form of fever up to $38.9^{\circ} \mathrm{C}$ and generalized muscle pain occurred. The symptoms resolved spontaneously within several hours. A gradual regression of skin lesions had been observed during treatment. In the second week of the treatment, left eye vision returned. According to the patient's ailments, the image was out of focus, with poorly saturated colors. After the treatment, the results of laboratory tests normalized: CRP concentration $(3.27 \mathrm{mg} / \mathrm{l})$ and the activity of aminotransferases (ALT 42 U/1, AST 37 U/1). GGTP activity decreased threefold to $124 \mathrm{U} / 1(\mathrm{~N}<61)$.

The patient was discharged home in a good general condition with a recommendation of a follow-up at the Dermatology Outpatient Clinic 1, 3, 6, 9 and 12 months after the end of the treatment. A check-up at the Ophthalmology and Neurology Outpatient Clinic was recommended. The patient committed to inform his sexual partners about the need for a medical appointment, diagnostics and possible treatment.

During the follow-up visit one month after the end of treatment, the patient had complete remission of skin lesions and further improvement in vision. Syphilitic serological tests' titers decreased fourfold, VDRL (1/64) and TPHA (1/10240). The patient did not show up to the next check-up at the Dermatology Clinic.

\section{DISCUSSION}

According to the latest report of ECDC of 2020, in 2011-2017 there was a systematic increase in the number of syphilis cases in Europe. In 2018 the syphilis incidence rate was 7 per 100,000 population, it was nine times higher in men than in women, especially in the 25-34 age group $(29 / 100,000)$. In $69 \%$ of cases, the infection was acquired through sexual contact with MSM (3).

It has been proven that HIV infection increases the risk of acquiring syphilis, similarly, infection with Treponema pallidum predisposes to HIV infection. The presence of syphilitic lesions in the mucous membranes of the genital organs facilitates the entry of the virus $(2,7)$. It has also been shown that the spirochetal lipoproteins activate the expression of the macrophage chemokine receptor (C-C Motif Chemokine Receptor 5, CCR5), which increases HIV penetration into CD4+ cells (2). Coexisting HIV infection may change the clinical features and course of syphilis, and the response to treatment $(2,7)$. In one retrospective study of $\mathrm{HIV}+$ patients infected with syphilis, cases of symptomatic syphilis accounted for only $50 \%$. Among them, apart from cutaneous and mucosal, other symptoms were found in $21.8 \%$. In majority they concerned the eye, and severally pod postacią gorączki do $38,9^{\circ} \mathrm{C}$ i uogólnionych bólów mięśniowych. Objawy ustąpiły samoistnie w ciągu kilkunastu godzin. Podczas leczenia obserwowano stopniowe cofanie się zmian skórnych. W drugim tygodniu leczenia nastąpił powrót widzenia okiem lewym. Według relacji pacjenta obraz był nieostry, o mało nasyconych barwach. Po leczeniu, wyniki badań laboratoryjnych uległy normalizacji: stężenie CRP $(3,27 \mathrm{mg} / \mathrm{l})$ i aktywność aminotransferaz (ALT 42 U/1, AST 37 U/1). Aktywność GGTP obniżyła się trzykrotnie, do 124 U/1 $(\mathrm{N}<61)$.

Pacjenta $\mathrm{w}$ stanie ogólnym dobrym wypisano do domu z zaleceniami kontroli w Poradni Wenerologicznej po 1, 3, 6, 9 i 12 miesiącach od zakończenia leczenia. Zalecono kontrolę w Poradni Okulistycznej i Neurologicznej. Chory zobowiązał się do poinformowania partnerów seksualnych o konieczności wizyty lekarskiej, diagnostyki i ewentualnego leczenia.

W trakcie wizyty kontrolnej po miesiącu od zakończenia leczenia stwierdzono u pacjenta całkowita remisję zmian skórnych oraz dalszą poprawę widzenia. Miana kiłowych odczynów serologicznych uległy czterokrotnemu obniżeniu, VDRL (1/64) i TPHA (1/10240). Na kolejne kontrolne badanie w Poradni Wenerologicznej pacjent nie zgłosił się.

\section{DYSKUSJA}

Zgodnie $\mathrm{z}$ ostatnim raportem European Centre for Disease Prevention and Control (ECDC) z 2020 r., w latach 2011-2017 w Europie odnotowano systematyczny wzrost liczby przypadków kiły. W 2018 r. współczynnik zachorowalności na kiłę wynosił 7/100 000 populacji, był on dziewięciokrotnie wyższy w grupie mężczyzn niż kobiet, szczególnie w wieku 2534 lat (29/100 000). W 69\% przypadków zakażenie zostało nabyte drogą kontaktów seksualnych z MSM (3).

Udowodniono, że zakażenie HIV zwiększa ryzyko nabycia kiły, podobnie infekcja krętkiem bladym predysponuje do zakażenia HIV. Obecność kiłowych zmian w obrębie błon śluzowych narządów płciowych ułatwia wnikanie wirusa $(2,7)$. Wykazano ponadto, że lipoproteiny krętka bladego aktywują ekspresję chemokinowego receptora makrofagów (C-C Motif Chemokine Receptor 5, CCR5), co zwiększa przenikanie HIV do komórek CD4+ (2). Wspólistniejące zakażenie HIV może zmienić obraz kliniczny i przebieg kiły oraz odpowiedź na leczenie $(2,7)$. W jednym z retrospektywnych badań pacjentów z HIV zakażonych kiłą, przypadki objawowe kiły stanowiły jedynie $50 \%$. Wśród nich, poza skórnymi i śluzówkowymi, inne objawy stwierdzono u 21,8\% pacjentów. Najczęściej dotyczyły one narządu wzroku, a pojedyncze - zaburzeń ze strony układu pokarmowego i uogólnionej limfadenopatii (6). 
- disorders of the digestive system and generalized lymphadenopathy (6).

Eye involvement occurs in about $10 \%$ of the second and $2-5 \%$ of the third period syphilis cases (8). In HIV-infected people, eye involvement in the course of syphilis is statistically more common, it affects $35-75 \%$ of patients $(8,9)$. There are no characteristic symptoms of syphilis in the eye, it can be manifested as inflammation of any eye's structure. The uvea is most commonly involved, and less often the retina and the optic nerve (8). Increased severity of ophthalmic symptoms has been reported in patients with HIV co-infection $(7,10)$. The diagnosis of ocular syphilis is based on clinical symptoms, the appearance of abnormalities in ophthalmological examination and positive serological syphilis tests (2). In most cases (50$78 \%$ ), ocular syphilis is diagnosed due to serological tests for syphilis during the search for the cause of ophthalmic disorders $(8,11)$. In the presented patient, the sudden onset of visual disturbances, changes found in the retina and lens, combined with positive syphilitic tests' results, enabled us to diagnose the ocular syphilis.

Early syphilis with an ocular involvement is considered as early neurosyphilis (1). The spirochetes can penetrate the nervous system in the first-stage syphilis, and despite the absence of neurological symptoms, abnormalities indicating the inflammation in the cerebrospinal fluid (CSF) are found in $25-30 \%$ of cases. Such aberrations in CSF usually resolve spontaneously, but in $10-15 \%$ of cases the infection remains latent and in the future may become the starting point for late, severe changes in the nervous system (12). In the second stage of early syphilis and in the late syphilis in approximately $30 \%$ of untreated patients abnormalities indicative of inflammation in CSF can be found, usually without clinical symptoms. The symptoms occur only in $1-2 \%$ of cases and may include acute syphilitic meningitis, meningeal syphilis, cranial nerves' palsy, and ophthalmic and otorhinolaryngological (ENT) disorders. When inflammatory changes are found in the meninges of the base of the brain, cranial nerves, including the optic nerve, can be damaged (12).

In accordance with the 2014 International Union against Sexually Transmitted Infections (IUSTI) guidelines, lumbar puncture is recommended in a patient with serologically confirmed syphilis and presence of neurological syptoms, including sudden visual disturbances (13). Some experts also indicate the validity of lumbar puncture after diagnosis of syphilis in HIV-infected patients with CD4+ lymphocyte counts below $350 / \mathrm{mm}^{3}$ and/or serum VDRL levels above $1 / 32(1,13)$. Only in half of the ophthalmic syphilis cases, without other neurological symptoms,
Zajęcie narządu wzroku dotyczy około $10 \%$ przypadków kiły drugiego i 2-5\% trzeciego okresu (8). U osób zakażonych HIV zajęcie oka w przebiegu kiły występuje statystycznie częściej, dotyczy 35-75\% chorych $(8,9)$. Brak jest charakterystycznych objawów kiły narządu wzroku, może się ona manifestować jako zapalenie każdej struktury oka. Najczęściej zajęta jest błona naczyniowa, nieco rzadziej siatkówka i nerw wzrokowy (8). Donoszono o większym nasileniu objawów okulistycznych u pacjentów z koinfekcją HIV $(7,10)$. Rozpoznanie kiły narządu wzroku ustala się w oparciu o objawy kliniczne, obraz zmian w badaniu okulistycznym oraz dodatnie odczyny serologiczne w kierunku kiły (2). W większości przypadków (50-78\%) kiła narządu wzroku rozpoznawana jest dzięki wykonaniu badań serologicznych w kierunku kiły w trakcie poszukiwania przyczyny zaburzeń okulistycznych $(8,11)$. U przedstawionego pacjenta nagłe wystąpienie zaburzeń widzenia, zmiany stwierdzane w obrębie siatkówki i soczewki w połączeniu z dodatnimi odczynami kiłowymi pozwoliły rozpoznać kiłę narządu wzroku.

Kiła wczesna z zajęciem narządu wzroku jest traktowana jako wczesny neurosyphilis (1). Krętki przenikają do układu nerwowego już w kile pierwszego okresu i pomimo niewystępowania objawów neurologicznych, w 25-30\% przypadków stwierdza się zmiany zapalne w płynie mózgowo-rdzeniowym (PMR). Zmiany zapalne w PMR cofają się samoistnie, ale u 10-15\% zakażenie pozostaje w stanie utajenia i w przyszłości może stać się punktem wyjścia późnych, ciężkich zmian w układzie nerwowym (12). W drugim okresie kiły wczesnej oraz w kile późnej również u około 30\% nieleczonych chorych można stwierdzić zmiany zapalne w PMR, zwykle bez objawów klinicznych. Objawy występują jedynie w 1-2\% przypadków i mogą mieć postać ostrego kiłowego zapalenia opon mózgowo-rdzeniowych, kiły oponowo-naczyniowej, porażenia nerwów czaszkowych oraz zaburzeń okulistycznych i laryngologicznych. Przy lokalizacji zmian zapalnych w oponach podstawy mózgu, może dojść do uszkodzenia nerwów czaszkowych, w tym nerwu wzrokowego (12).

W przypadku wystąpienia u pacjenta z serologicznie potwierdzoną kiłą objawów neurologicznych, wśród których wymienione są nagłe zaburzenia widzenia, zgodnie z wytycznymi International Union against Sexually Transmitted Infections (IUSTI) z 2014 r., zalecane jest wykonanie punkcji lędźwiowej (13). Część ekspertów wskazuje również zasadność wykonywania punkcji lędźwiowej po rozpoznaniu kiły u pacjentów zakażonych HIV, u których liczba limfocytów CD4+ jest niższa niż $350 / \mathrm{mm}^{3} \mathrm{i} /$ lub surowicze miano VDRL przekracza 1/32 $(1,13)$. Jedynie w połowie przypadków kiły narządu wzroku, bez innych objawów neurologicznych, wyniki badania płynu mózgowo-rdzeniowego spełniają kryteria rozpoznania zakażenia ośrodkowego układu 
the results of the cerebrospinal fluid test meet the diagnostic criteria of central nervous system (CNS) infection $(8,11)$. The 2008 IUSTI diagnostic criteria for CNS syphilis include a positive CSF VDRL test or positive CSF spirochetal test result in combination with a mononuclear cell count $>5-10 / \mathrm{mm}^{3}$. According to the criteria of the Polish Dermatological Society (PTD) of 2018, CNS syphilis can be diagnosed in the presence of clinical symptoms suggestive of neurosyphilis (neurological, psychiatric, ophthalmic, ENT) in the combination with specific abnormalities in the CSF. These include a reactive CSF VDRL test (in the absence of contamination of the CSF with blood) or a positive spirochetal test along with the number of CSF leukocytes $>5 / \mathrm{ml}$ (with HIV co-infection $>20 / \mathrm{ml}$ ) and/or a CSF protein concentration $>45 \mathrm{mg} / \mathrm{dl}$ (14). In the described patient, CSF VDRL was negative, spirochetal tests' results were positive and the cytosis was low. The patient's concentration of albumin in CSF was normal, while a significantly elevated concentration of IgG was found, which may indicate the intrathecal production of antibodies. According to the diagnostic criteria for the neurosyphilis mentioned above (IUSTI 2008, PTD 2018), the abnormalities in the cerebrospinal fluid observed in the patient were not satisfactory for making or excluding the diagnosis of central nervous system syphilis. The patient in the course of retroviral disease presented with profound peripheral lymphopenia, which may be the reason for a falsely low cell count in the CSF. On the other hand, HIV infection itself can also cause increased cytosis in the CSF, which makes it difficult to interpret our patient's results unambiguously (5).

According to the latest opinions of the European Academy of Dermatology and Venereology (EADV) from 2020, the diagnostic criteria of neurosyphilis used so far are not sufficiently sensitive or specific (1). In only one third of all CNS syphilis cases VDRL in CSF is positive. Also, the protein concentration and the number of mononuclear cells may be normal $(1,12)$.

Ocular syphilis should be treated like CNS syphilis, regardless of the result of CSF examination (1). Penicillin is the drug of choice in all forms and periods of acquired syphilis. In the CNS disease, crystalline penicillin is used intravenously at a dose of 18-24 MU a day in 6 divided doses or as a continuous infusion. HIV-infected patients with CNS syphilis should also receive such treatment $(1,14)$. The presented patient was treated with crystalline penicillin according to the above scheme. A complete recovery of vision was achieved, indicating the spirochetal background of ophthalmic disorders.

The prognosis for improvement in eyesight in patients with ocular syphilis depends on the timing nerwowego (OUN) $(8,11)$. Kryteria rozpoznania kiły OUN według IUSTI z 2008 r. obejmują dodatni odczyn VDRL w PMR albo dodatnie wyniki odczynów krętkowych w płynie w połączeniu z liczbą komórek jednojądrowych $>5-10 / \mathrm{mm}^{3}$. Zgodnie z kryteriami Polskiego Towarzystwa Dermatologicznego (PTD) z 2018 r., kiłę OUN można rozpoznać w przypadku wystąpienia objawów klinicznych sugerujących neurosyphilis (neurologicznych, psychiatrycznych, okulistycznych, laryngologicznych) w połączeniu z określonymi odchyleniami w PMR. Należy do nich reaktywny odczyn VDRL w PMR (przy braku zanieczyszczenia PMR krwią) albo dodatni odczyn krętkowy łącznie z liczbą leukocytów w PMR > 5/ml (przy koinfekcji HIV > 20/ml) i/lub stężeniem białka w PMR $>45 \mathrm{mg} / \mathrm{dl}$ (14). U opisywanego pacjenta w PMR stwierdzono ujemny odczyn VDRL, dodatnie odczyny krętkowe i niską cytozę. U chorego stężenie albumin w PMR było prawidłowe, natomiast stwierdzono znacznie podwyższone stężenie IgG, co może wskazywać na intratekalną produkcję przeciwciał. Zgodnie z powyższymi kryteriami rozpoznania kiły OUN (IUSTI 2008, PTD 2018), zaobserwowane u pacjenta odchylenia $\mathrm{w}$ płynie mózgowo-rdzeniowym nie pozwalają na pewne rozpoznanie kiły ośrodkowego układu nerwowego, ani na jej wykluczenie. Pacjent w przebiegu choroby retrowirusowej prezentował głęboką limfopenię obwodową, co może być przyczyną fałszywie zaniżonej liczby komórek w PMR. Z drugiej strony, samo zakażenie HIV może również powodować podwyższoną cytozę w PMR, co utrudnia jednoznaczną interpretację wyników naszego pacjenta (5).

Według najnowszych opinii European Academy of Dermatology and Venereology (EADV) z 2020 r., dotychczas stosowane kryteria rozpoznania neurosyphilis nie są jednak dostatecznie czułe ani swoiste (1). Dodatni VDRL w PMR stwierdza się tylko w 1/3 wszystkich przypadków kiły ośrodkowego układu nerwowego. Również stężenie białka i liczba komórek jednojądrowych mogą być w normie $(1,12)$.

Kiła narządu wzroku powinna być leczona tak jak kiła OUN, niezależnie od wyniku badania PMR (1). Penicylina jest lekiem z wyboru we wszystkich postaciach i okresach kiły nabytej. W kile OUN penicylina krystaliczna stosowana jest dożylnie w dawce 18-24 $\mathrm{mln} \mathrm{j}$./dobę w 6 dawkach podzielonych lub we wlewie ciągłym. Takie leczenie powinni również otrzymywać chorzy z kiłą OUN zakażeni HIV $(1,14)$. Przedstawiony pacjent był leczony penicyliną krystaliczną, według powyższego schematu. Uzyskano całkowity powrót widzenia, co wskazuje na krętkowe tło zaburzeń okulistycznych.

Rokowanie co do poprawy wzroku u pacjentów z kiłą oczną zależy od czasu wdrożenia właściwego leczenia. Przy włączeniu antybiotykoterapii do $28 \mathrm{dni}$ od wystąpienia objawów ze strony narządu wzroku, co 
of appropriate treatment. The prognosis is good when antibiotic therapy is started up to 28 days after the onset of symptoms in the organ of vision, which was implemented in the described patient (15).

Syphilitic hepatitis develops in $10 \%$ of patients with syphilis. Half of them have elevated levels of transaminases and alkaline phosphatase. There may be an enlargement of the liver with its tenderness, less often jaundice. Syphilitic hepatitis can lead to hepatocytes' necrosis, narrowing of the bile ducts, and portal vasculitis. The healing process is accompanied by fibrosis, which can lead to cirrhosis of the liver. In late syphilis, gummas imitating neoplastic metastases may occur (2). The normalization of transaminases' activity after the treatment of syphilis, despite the chronic administration of potentially hepatotoxic medications, proves the etiology of syphilitic hepatitis and its effective treatment. The effectiveness of the treatment used in the presented patient is also proven by the resolution of clinical symptoms in the skin and eye, and a fourfold decrease in the titer of treponemal and non-treponemal tests observed one month after the end of the treatment.

The Jarish-Łukasiewicz-Herxheimer reaction that occurred in our patient is an acute reaction arising on the first day of antibiotic therapy for syphilis, with fever, headaches, muscle aches, chills, and, less often, convulsions. Its cause is not fully explained. It is assumed that it is the body's reaction to the toxins released as a result of the bacteriolysis of spirochetes. In early syphilis, it is common (10-25\%), much less frequent in late syphilis. Its incidence is probably greater with administration of penicillin than doxycycline. Symptoms resolve spontaneously usually within 24 hours without significant sequelae. Due to the risk of serious complications, in the onset of this reaction, special supervision is required in patients with nervous system or eye involvement, patients with late cardiovascular syphilis, as well as newborns and pregnant women. Antipyretic drugs are usually used in the treatment. Preventive treatment can be prednisolone 20-60 mg daily, 24 hours before antibiotic therapy and during the first two days of treatment (1).

After treatment of syphilis, close clinical and serological monitoring is recommended at intervals of 1, 3, 6 months after the end of treatment and then every 6 months (15). Patients at high risk of reinfection, including MSM and HIV-infected, should be regularly screened for syphilis, preferably every 3 months $(1,5)$.

In the described case, the patient did not come to the next appointments, despite our numerous attempts to contact him. Further serological testing is planned as a part of the routine screening at the HIV Consulting Center for Adults with HIV and AIDS. uczyniono u opisywanego pacjenta, rokowanie jest dobre (15).

W przebiegu kiły u $10 \%$ chorych dochodzi do kiłowego zapalenia wątroby. U połowy z nich stwierdza się podwyższone aktywności transaminaz i fosfatazy zasadowej. Może wystąpić powiększenie wątroby z jej tkliwością, rzadziej żółtaczka. Kiłowe zapalenie wątroby może prowadzić do martwicy hepatocytów, zwężenia przewodów żółciowych, zapalenia naczyń wrotnych. Proces gojenia przebiega $\mathrm{z}$ włóknieniem, mogącym prowadzić do marskości wątroby. W kile późnej mogą wystąpić kilaki, imitujące przerzuty nowotworowe (2). Normalizacja aktywności transaminaz po leczeniu kiły, pomimo przewlekłego przyjmowania przez pacjenta leków potencjalnie hepatotoksycznych, świadczy o etiologii kiłowej zapalenia wątroby i jego efektywnym leczeniu. Skuteczności zastosowanego leczenia u przedstawionego pacjenta dowodzi również ustąpienie objawów klinicznych ze strony skóry i narządu wzroku oraz czterokrotny spadek miana odczynów krętkowych i niekrętkowych stwierdzony miesiąc po zakończeniu leczenia.

Reakcja Jarisha-Łukasiewicza-Herxheimera, która wystąpiła u naszego pacjenta, jest ostrym odczynem, występującym w pierwszej dobie antybiotykoterapii kiły, przebiegającym z gorączką, bólami głowy, mięśni, dreszczami, rzadziej drgawkami. Jej przyczyna nie jest do końca wyjaśniona. Przypuszcza się, że jest to reakcja organizmu na uwolnione wskutek rozpadu krętków toksyny. We wczesnej kile występuje często (10-25\%), znacznie rzadziej w kile późnej. Prawdopodobnie częstość jej występowania jest większa przy leczeniu penicyliną niż doksycykliną. Objawy ustępują samoistnie zwykle w ciągu 24 godzin, bez istotnych następstw. Ze względu na ryzyko ciężkich powikłań, w przypadku wystąpienia tej reakcji szczególnego nadzoru wymagają pacjenci z zajęciem układu nerwowego czy narządu wzroku, chorzy na kiłę późną sercowo-naczyniową, jak również noworodki i kobiety w ciąży. W leczeniu zwykle stosuje się leki przeciwgorączkowe. Zapobiegawczo można podawać prednizolon 20-60 mg dziennie, 24 godziny przed włączeniem antybiotykoterapii oraz przez dwa pierwsze dni leczenia (1).

Po leczeniu kiły zalecana jest ścisła kontrola kliniczna i serologiczna w odstępach $1,3,6$, miesięcy od zakończenia leczenia i następnie raz na 6 miesięcy (15). Pacjenci o wysokim ryzyku reinfekcji, w tym MSM i zakażeni HIV, powinni być regularnie badani w kierunku kiły, optymalnie co 3 miesiące $(1,5)$.

W opisanym przypadku pacjent nie zgłosił się na kolejne wyznaczone wizyty, pomimo licznych prób kontaktu z naszej strony. Dalsze badania serologiczne planowane są w ramach rutynowych kontroli w Punkcie Konsultacyjnym dla Dorosłych Zakażonych Wirusem HIV i Chorych na AIDS. 


\section{CONCLUSIONS}

Patients with the retroviral infection are advised to report to the screening tests for syphilis during subsequent follow-up visits, not only at initial diagnosis.

Routine screening for Treponema pallidum infection is recommended to all patients with sudden visual impairment.

Delaying ocular syphilis treatment beyond 28 days after the onset of symptoms may lead to irreversible loss of vision.

\section{REFERENCES}

1. Janier M, Unemo M, Dupin N, et al. 2020 European guideline on the management of syphilis. J Eur Acad Dermatol Venereol. 2021;35(3):574-88.

2. Wojdała E. Kiła. Wydaw Czelej Lublin 2018, Rozdziały: Epidemiologia, strona 11-3, Zmiany w innych narządach $w$ przebiegu kiły nabytej, strona 108-11, Kiła i koinfekcja HIV strona 147-64.

3. European Centre for Disease Prevention and Control 24 Apr 2020. Syphilis - Annual Epidemiological Report for 2018 Surveillance Report (https://www. ecdc.europa.eu/en/publications-data/syphilisannual-epidemiological-report-2018).

4. Serwin AB, Grochowska A, Flisiak I. Men treated for syphilis in Białystok, Poland, 2014-2018. Przegl Epidemiol 2019;73(3):329-35.

5. Wojas-Pelc A, Pastuszczak $M$, Serwin AB, et al. Syphilis. Diagnostic and therapeutic recommendations of the Polish Dermatological Society. Part 1: early and late syphilis. Dermatology Review/Przegląd Dermatologiczny, 2018;105(5):563-81.

6. Prieto P, Imaz A, Calatayud L, et al. Extracutaneous atypical syphilis in HIV-infected patients. Med Clin (Barc) 2017 Dec 7;149(11):488-92.

7. Tipple C. Impact of HIV-1 infection on the clinical presentation of syphilis in men who have sex with men. Sex Health 2015;12(2):110-8.

8. Klein A, Fischer N, Goldstein M, et al. The great imitator on the rise: ocular and optic nerve manifestations in patients with newly diagnosed syphilis. Acta Ophthalmol 2019;97:641-7.

9. Gutierrez B, Gayet S, Bertolino J, et al. La syphilis oculaire, une pathologie ré-émergente : série de 12 patients au CHU de Marseille en 2017 [Ocular syphilis, a re-emergent pathology: Series of 12 patients in one Hospital, 2017]. Rev Med Interne 2020;41(3):160-7.

10. Cunningham ET Jr, Eandi CM, Pichi F. Syphilitic Uveitis. Ocular Immunol Inflamm 2014;22: 2-3.

\section{WNIOSKI}

U pacjentów z rozpoznanym zakażeniem retrowirusowym wskazane są badania screeningowe w kierunku kiły nie tylko przy rozpoznaniu, ale również podczas kolejnych wizyt kontrolnych.

U wszystkich pacjentów z nagłym upośledzeniem funkcji narządu wzroku zalecane jest rutynowe badanie w kierunku zakażenia krętkiem bladym.

Opóźnienie wdrożenia leczenia kiły ocznej powyżej 28 dni od wystąpienia objawów może prowadzić do nieodwracalnej utraty wzroku.

11. Bazewicz M, Lhoir S, Makhoul D, et al. Neurosyphilis cerebrospinal fluid findings in patients with ocular syphilis. Ocul Immunol Inflamm 2021;29(1):95-101.

12. Marra CM, Maxwell CL, Smith SL, et al. Cerebrospinal fluid abnormalities in patients with syphilis: association with clinical and laboratory features. J Infect Dis 2004 1;189:369-76.

13. Janier M, Hegyi V, Dupin N, et al. European guideline on the management of syphilis. Przegl Dermatol 2014;102(5):459-75.

14. Wojas-Pelc A, Pastuszczak M, Serwin AB, et al. Syphilis. Diagnostic and therapeutic recommendations of the Polish Dermatological Society. Part 2: neurosyphilis, syphilis in pregnancy and congenital syphilis. Przegl Dermatol 2018;105(5):582-92.

15. Tsuboi M, Nishijima T, Yashiro S, et al. Prognosis of ocular syphilis in patients infected with HIV in the antiretroviral therapy era. Sex Transm Infect 2016;92(8):605-10.

Received: 31.05.2021

Accepted for publication: 13.07.2021

Otrzymano: 31.05.2021 r.

Zaakceptowano do publikacji: 13.07.2021 r.

\section{Address for correspondence:}

\section{Adres do korespondencji:}

Anna Olszewska

Klinika Dermatologii i Wenerologii Uniwersytetu Medycznego w Białymstoku,

ul. Żurawia 14A,

15-540 Białystok

email: anna.m.sosnowska@gmail.com 